\title{
モーダル定数の有限要素法解析と実験による翼軸連成㧖り振動評価*
}

\author{
岡 部 明*1, 塩幡 宏 規*2, 工藤 健*1 \\ 依田秀夫*3, 桜井茂雄*4, 中島大喜*5
}

\section{Rotor-Blade Coupled Torsional Vibration Evaluation Using Modal Parameters Based on FEM Analysis and Experiment}

\author{
Akira OKABE*6, Koki SHIOHATA, Takeshi KUDO, \\ Hideo YODA, Shigeo SAKURAI and Daiki NAKAJIMA \\ ${ }^{* 6}$ Graduate School of Science and Engineering, Ibaraki University, \\ 4-12-1 Nakanarusawa, Hitachi-shi, Ibaraki, 316-8511 Japan
}

\begin{abstract}
Quasi-Modal technique is used for rotor-blade coupled torsional vibration analysis, because of its unique characteristics to provide a visual reduced model. In this paper we propose the hybrid method to calculate rotor-blade coupled torsional vibration of the model rotor of two disks with continuously coupled blades using FEM based quasi-modal parameters of blade-disk system. The result of hybrid method is compared with the full FEM analysis of the model rotor. The hybrid method shows the good accord with the full FEM analysis. This hybrid method has the advantage for faster design calculation repetition. The rotation test of model rotor is executed and measured results are compared with the calculated results to show the good accordance. The calibration procedure of modal parameters based on the measured blade-disk frequencies is also presented in order to show that the quasi-modal modeling is practicable method to feed back test results to analytical model for better accuracy.
\end{abstract}

Key Words: Vibration of Rotating Body, Torsional Vibration, Coupled Vibration, Quasi-Modal Transformation, Finite Element Method

\section{1. 暂 言}

最近の蒸気タービン低圧段長翼の大型化は振動数離 調，岡性強化やダンピング向上等を考慮して，図 1(a) に示すように全周の翼がインテグラルカバー, タイボ ス等で連結される全周 1 リング構造を成してディスク 外周に連結されることから，ディスクと翼で連成して より複雑な振動モードが発生する.

このようなディスク・翼系の固有振動モードは節直 径数で整理できる. そのひとつとして，翼が全周同相 で振動するいわゆる節直径数=0 次のアンブレラモー ドがあり，この同相振動の周方向成分が図 1(b)に示す ようにロータのねじり振動と連成する. 一方で軸のね じり振動が翼の周方向慣性力となり，翼の同相振動を 励起することになる.

* 原稿受付 2010 年 4 月 20 日.

*1 正員, 茨城大学大学院理工学研究科(画 $316-8511$ 日立市中 成沢町 4-12-1)

*2 正員, フェロー, 茨城大学大学院理工学研究科.

*3 (株) 日立製作所日立事業所 (苾317-8511 日立市幸町 3-1-1).

*4 正員, フェロー, (株) 日立製作所日立事業所.

$* 5$ 茨城大学大学院理工学研究科.

E-mail : akira.okabe.fn@hitachi-pt.com

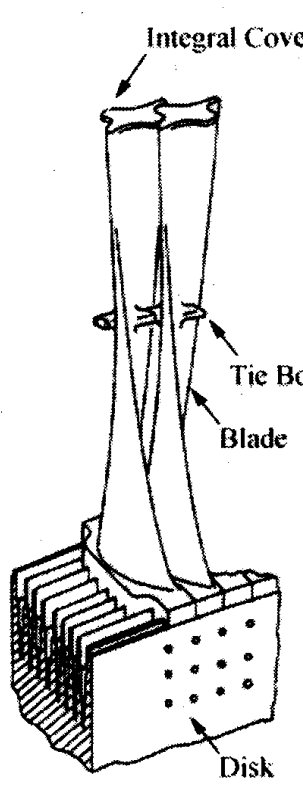

(a)
Blade-Disk: Umbrella Tangential Vibration

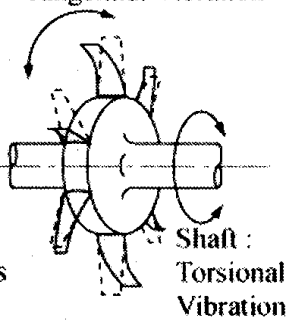

Blade-Disk: Umbrella Axial Vibration

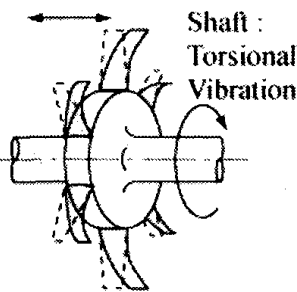

(b)
Fig.1 Rotor-blade coupled vibration 
アンブレラモードについては，大型タービン発電機 で種々の解析方法や実機測定が行われてきた ${ }^{(1-6)}$. 筆者 らは変形モードと拘束モ一ドを用いた擬基淮座標変換 法にて座標変換し, 翼をば㱛-質量 1 自由度等価縮小翼 モデルに置換することで翼軸連成振動を解析する方法 を提案してきた(7-9).ささらに擬基準座標変換法による等 価縮小モデル化をべ一スとして，1 本のタービン低圧 ロータで翼軸連成ねじり振動数を工場実測して等価縮 小定数（質量とばね）を決め,このデータセットを利 用することで，タービン発電機全体系の実機ロータ系 翼軸連成振動数を精度良く推定できることをフィール ド試験で確認した ${ }^{(10)}$.

一連の解析はディスク・翼系の非連成固有振動数と 非連成モードの計算がまず必要になるが，従来は全周 1 リング構造の周期性を考慮した伝達マトリックス法 を使用してきた(11)。しかし，前述のごとく翼連結構造 が複雑化するにつれて，伝達マトリックス法では詳細 構造の影響を使い勝手よく反映することが困難になっ てきたため, 詳細構造を 3 次元有限要素法でモデル化 して評価するようになってきた.

一方，CAE 技術の発達により，3 次元モデリングに より流体解析から構造解析までを沉用有限要素法で一 貫してシミュレーションすることが設計開発現場の主 流となりつつあり，一般に複数の汎用有限要素法プロ グラムが利用されている。ここではそのひとつである ANSYS ${ }^{\circledR}$ を振動解析に使用している.

さらには, 大型圧縮機とその駆動モ一タとの軸系は, インバータ制御の普及や電気系統の複雑化により㨝り 加振周波数や機械・電気系㨭り連成振動系も複雑化す るケースが増大しており，擬基準座標変換法による等 価縮小モデル化手法を，汎用的に応用す心゙き対象も拡 大すると考えられる。

本論文では，汎用有限要素法 ANSYS ${ }^{\circledR}$ にて翼・ディ スク系をばね-質量 1 自由度等価縮小モデルに置換し て翼軸連成振動を解析するハイブリッドの方法と， 翼・ディスク・軸モデル軸系の完全 3 次元有限要素法 解析結果とを比較する，その結果，両手法が同等の解 析結果を与えることを示し，前者が完全 FEM 手法よ り短時間で解析できる効果を確認する，さらには，軸 系モデル実験での翼軸連成㧖り振動アンブレラモード の測定結果と比較して，等価縮小解析の手法の妥当性 確認すると共に，実測データベースでの等価モーダル 定数の補正方法を提案し, 実験結果の7イードバックが容易 に出来る本手法の実用上の有効性を示す。

\section{おもな 記 号}

a : 連成係数

$k_{i j} \quad$ : ばね定数

$\left[K_{1}\right],\left[K_{3}\right] \quad$ : 回転軸と翼の剛性行列

$k_{23} \quad$ : 回転軸と翼の連結剛性

$\left[M_{1}\right],\left[M_{3}\right]$ : 回転軸と翼の質量行列

$m_{\delta}=\delta^{t} M_{3} \delta:$ 翼系を岡体とした総質量 $\bar{M}_{3}$ または極慣性モーメント $I_{p}$

$m^{*} \quad$ : 翼系のモーダル質量

$m_{c}^{*} \quad:$ 翼系の連成モーダル質量

$m_{e q}, \quad k_{e q}$ : 等価質量と等価ばね定数

$\eta \quad$ : 翼系固有モードの重み值

$x_{2} \quad$ : 翼ボス部の変位（絶対座標）

$X_{3} \quad$ : 翼系の変位ベクトル (絶対座標)

$x_{3}^{*} \quad$ : 等価質量節点の変位（絶対座標）

$\Delta m \quad$ : 残留質量

$\phi, \omega$ : 翼系非連成固有モード，振動数

$\phi_{t} \quad$ : 翼系非連成固有モード周方向成分

$\phi_{a} \quad$ : 翼系非連成固有モード軸方向成分

$\phi_{r} \quad$ : 翼系非連成固有モード半径方向成分

\section{2. 実鏂装置と方法}

$2 \cdot 1$ 供試軸系諸元 タービンロータの㨝り振動 系モデルとして，図 2 に示すような一様軸の両軸に翼 車がついている軸系を考える．このような構成の軸系 としては蒸気タービン低圧ロータによく見られる構成 である. タービン発電機系では発電機につながれる電 力系統に含まれる倍周波数成分 $2 f$ ( $f$ 系統周波数) が， 翼軸連成振動を励起することから，実機イメージを想 定して固有振動数が $100 \mathrm{~Hz}(=2 \times 50 \mathrm{~Hz})$ 程度となるよう に軸系諸元を考虑した．実験回転数については，実際 のタービン発電機系の回転数は $1500 \mathrm{rpm}-3600 \mathrm{rpm}$ であ るが，実験の安全性を考慮し本試験は 600 rpm で実験 することとした。

本実験の目的が翼の振動数と軸の㨝り振動の連成効 果で発生する振動現象の把握であるので，翼系の振動 数については，実機の振動数レベルも想定し，かつ軸 系の固有振動数と近接して連成しやすいように約 $80 \mathrm{~Hz}$ オーダーになるように設計してある. 


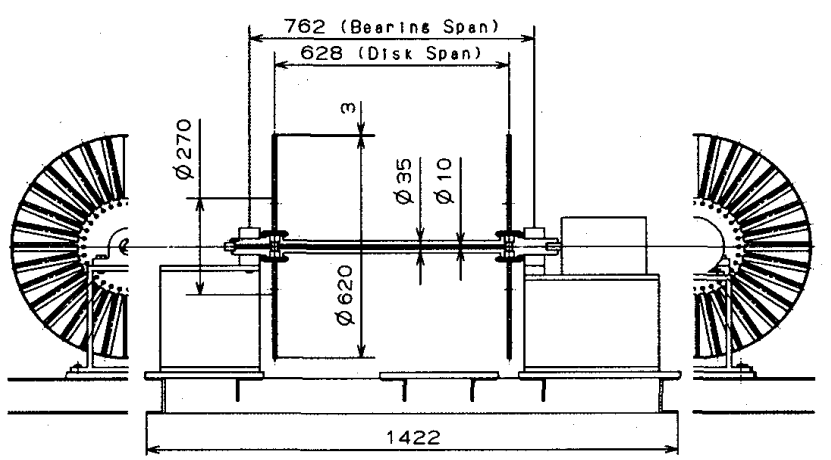

Fig. 2 Test rotor system

翼車の構造を図 3 に，実験装置の外観図を図 4 に示 す. 翼は矩形単一断面の梁で模擬した. 翼長は $175 \mathrm{~mm}$, 板厚は $3.2 \mathrm{~mm}$ とした. ダブルフロー型タービンを想定 し, 外径 $270 \mathrm{~mm}$ で, 厚み $10 \mathrm{~mm}$ のディスク外周に軸 に対して $60^{\circ}$ で翼を取り付けた左側ディスクと $60^{\circ}$ で取り付けた右側ディスク 2 枚で翼と軸を構成しアン ブレラモードを発生し易くしている. 各翼は板圧 $3 \mathrm{~mm}$ のカバーで連結されているが, この翼 32 枚がディスク 外周に全周 1 リング構造で連結されている. 全周 1 リ ング構造は個々の翼の製作誤差による固有値のバラツ キを少なくし翼車として一体の動きを円滑にしている.

翼車の翼, ディスク, カバーは一体削りだしで 2 枚 製作した。供試モデルの回転時の安全強度を十分確保 する為に，材質はジュラルミンとした． 2 枚のディス クを連結する軸は内径 $10 \mathrm{~mm}$ で, 外径は $35 \mathrm{~mm}$ とした。 この軸はディスク中心間距離が $628 \mathrm{~mm}$ である.この 軸系を回転させるために，軸の一方の端に駆動用のモ 一タ $(0.75 \mathrm{kw})$ が取り付けられている.

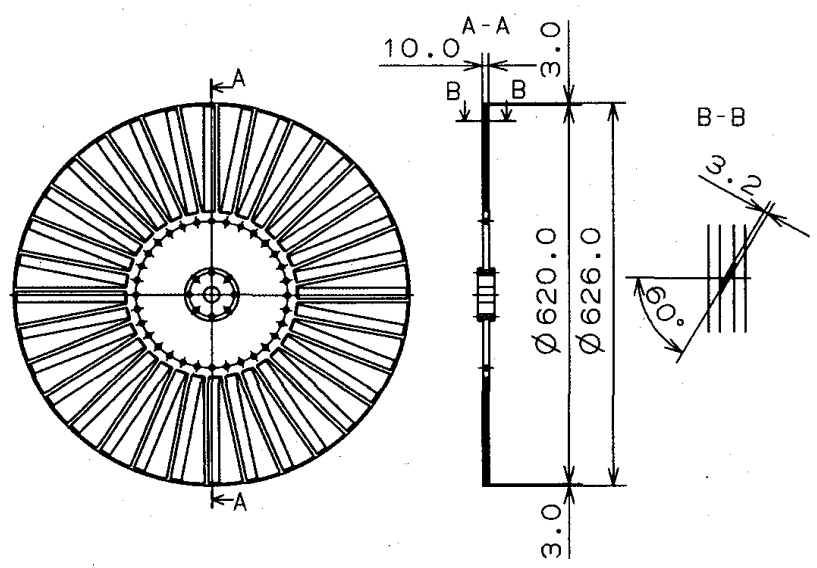

Fig. 3 Test disk with continuous coupled blades

$2 \cdot 2$ 実験方法およひ使用機器 振動数の測定は 600 rpm 回転時の連成振動数測定と, 単独ディスクの製 作精度を確認するために, 静止時の固有振動数測定も 実施した。静止時の固有振動数及びモードの測定は打
撃による応答をFFTで周波数分析して解析した. モ一 ド解析はFFT のモードアニメーション機能を使い，高 次の節直径数モードまで確認した。

タービンロータモデルの回転試験時は，翼上に貼付 したストレンゲージからの出力を, 軸中心孔を通した 配線によりスリップリングに接続に，これを介してス トレインアンプに通した後, FFT アナライザーにて周 波数分析をして求めた。

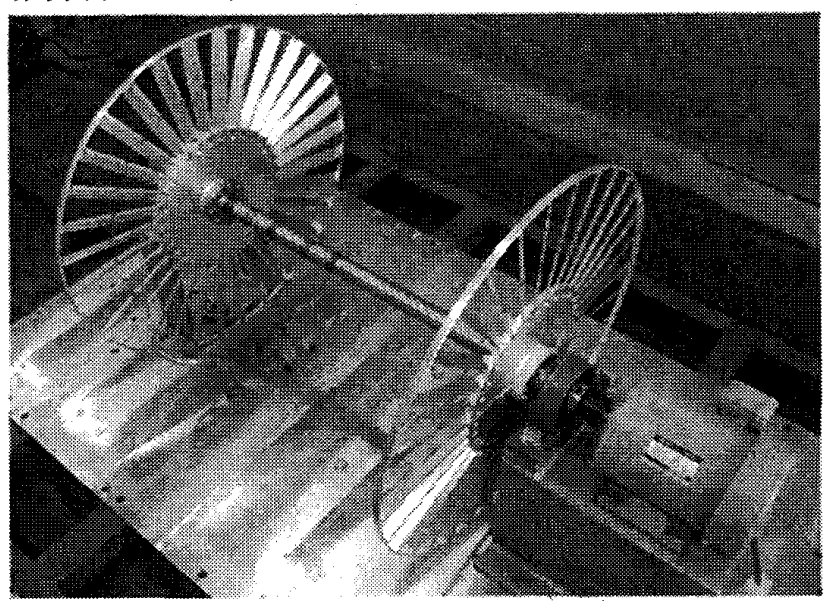

Fig. 4 Test rotor system view

\section{3. 連成振動解析}

3・1 翼・ディスク系のモーダル量計算方法 翼 系の固有值問題を図 5 (a) に示寸多質点系で説明する. 左側の 3 個の丸印が軸系（主系）で, 右側の 3 個の角 印が翼系（従系）を模式化している．雨者の境界であ る節点 $x_{2}$ が翼系を軸に固定する節点である.

非連成系では同図(b)のように, 軸系としては剛 体翼が先端 $x_{2}$ に付いたモデルを考える．翼系とし ては同図(c)のように $x_{2}=0$ なる条件での翼振動を 対象とする。ここで，同図(c)の翼単独系にモード 合成法を適用して縮小モデルを作成する，翼系等 価 1 質点は，図 5 (d) のように翼軸全体としては節点 $x_{2}$ に連結されたモデルとなる. すなわち, 翼系の $1 つ$ の振動モードを代表する等価質点 $x_{3}^{*}$ が右端に新設さ れる.この節点の等価質量とばね定数は式(1) (3)で決 められ，翼系の物理的全質量が維持されるような仕組 みになっている.この詳細については既発表の文献 (10)に詳述されているので，これを参照されたい。

$$
\begin{aligned}
& m_{e q}=a^{2} m^{*}=\text { 等価質量 } \\
& k_{e q}=\omega^{2} m_{e q}=\text { 等価ばね定数 } \\
& \Delta m=m_{\delta}-m_{e q}=\text { 残留質量 }
\end{aligned}
$$




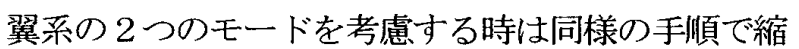
小モデル化を行い，2つの等価質点が図 5 (e) のよう に新設される.

実際の翼系の固有モ一ドは, 周方向成分 $\phi$ および軸 方向成分 $\phi_{a}$ ならびに半径方向成分 $\phi_{r}$ を持っている. 3 方向成分の総和をとったモーダル質量は次式で計算さ れる.

$$
m^{*}=\phi_{t}^{t} M_{3} \phi_{t}+\phi_{a}^{t} M_{3} \phi_{a}+\phi_{r}^{t} M_{3} \phi_{r}
$$

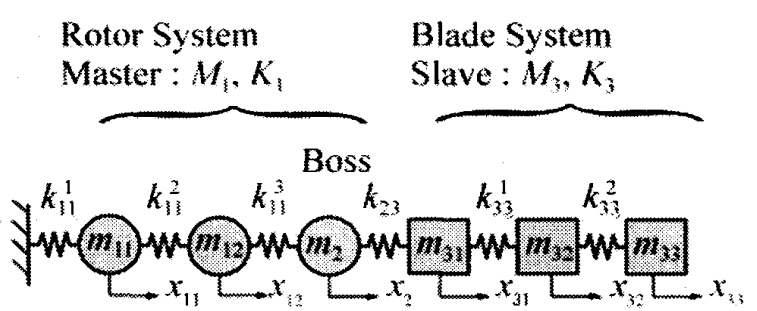

(a) shaft and blade coupled system

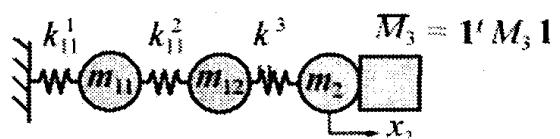

(b) shaft system (uncoupled)

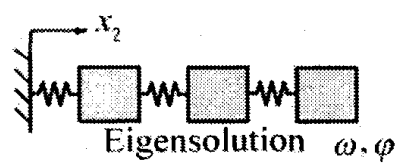

(c) blade system (uncoupled)

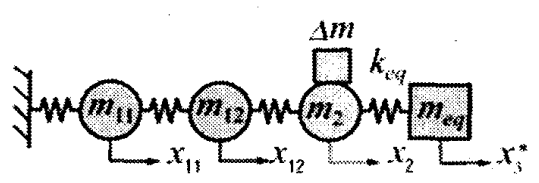

(d) equivalent reduced system ( 1 blade eigenmode)

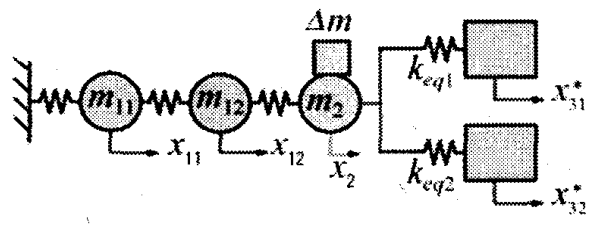

(e) equivalent reduced system ( 2 blade eigenmodes)

Fig. 5 Principle of reduced modeling procedure

一方，翼系にとってボス部が境界点で，軸ねじり変 位 $\theta$ が強制変位入力だから, 翼各点の変位は半径 $r$ を かけた值である. 翼を半径方向に 5 分割し, 翼先端か ら翼根元に向かって各半径方向位置を $r_{i}(i=1,2,3,4,5)$ と すれば，変形モード $\delta=\left[\begin{array}{lllll}r_{1} & r_{2} & r_{3} & r_{4} & r_{5}\end{array}\right]^{t}$ と定義 される. 従って,

$$
m_{\delta}=\delta^{t} M_{3} \delta \equiv I_{p}=\text { 極慣性モーメント }
$$

さらに，連成モーダル質量 $m_{c}^{*}$ は次式で計算される.

$$
m_{c}^{*}=\delta^{t} M_{3} \phi_{t}
$$

連成係数は次式となる。

$$
a=\frac{m_{c}^{*}}{m^{*}}=\frac{\delta^{t} M_{3} \phi_{t}}{\phi_{t}^{t} M_{3} \phi_{t}+\phi_{a}^{t} M_{3} \phi_{a}+\phi_{r}^{t} M_{3} \phi_{r}}
$$

3.2 有限要素法によるモーダル量計算 前節で説 明した手法を FEM で解析した固有振動モードに適用 する. 対象とするモデルは図 4 に示した様に全周 1 リ ング構造であるので，翼 1 本分に相当するディスク・ 翼・カバー分のモデルをソリッド要素（各節点での 3 方向変位のみを考慮し，傾きは無視．）で作成し，周 期境界条件を適用した。図 6 に計算に使用したメッシ ユ図を示す.

有限要素法での計算結果を格納したデータファイル から必要なデータを読み込みモーダル量を計算した。

以下，この処理フローを具体的に示寸.

ステップ $1:$ 計算基本情報の読込

（要素データ，節点座標データ，境界条件データ， 材料データ，周期境界データ）

ステップ 2 : 周期境界固有值解析の実行

注 : ANSYS ${ }^{\circledR}$ の場合は節点番号 1 から NE（節点数） は固有振動モ一ドの実部 $(R e)$ ，節点番号 $\mathrm{NE}+1$ から 2XNE は固有振動数モードの虚部 (Im) になっている. 円周方向角度 $\theta$ の位置にある翼の固有振動モードは

$\operatorname{Re}(x) \cos (\theta)+\operatorname{Im}(x) \sin (\theta)$ で表せる.

ステップ $3:$ 変位の正規化

最大半径位置の円周方向角変位（円周方向変位/半 径）が 1 となるように正規化しておく．（変位は円筒 座標系で計算されている。)

ステップ $4:$ 各節点の分担質量の計算

各要素の体積と節点番号を取得し，要素の質量を各 節点に等分配する.

$$
\text { ステップ } 5 \text { : モーダルパラメータの計算 }
$$

モーダルパラメータの定義式に従って有限要素モデル の全要素について計算する.

ソリッド要素に対し, 各節点の質量を $\Delta m_{i}$, 節点の座 標を $x_{i}, y_{i}, z_{i}$, 円筒座標系での翼先端の周方向変 位で正規化された半径方向変位を $u_{i}$, 周方向変位を $v_{i}$, 軸方向変位を $w_{i}$ とすると, 固有振動数を $\omega \mathrm{rad} / \mathrm{s}$ と して，下記式で等価定数を計算できる.
Mass $\left(m_{\delta} \mathrm{kg}\right)$
$\sum^{N} \Delta m_{i}$ 
Moment of Inertia $\left(I p \mathrm{~kg} \mathrm{~m}^{2}\right) \quad \sum^{N} \Delta m_{i}\left(x_{i}^{2}+y_{i}^{2}\right)$

$\operatorname{Modal}$ Mass $\left(m^{*} \mathrm{~kg}\right) \quad \sum^{N} \Delta m_{i}\left(u_{i}^{2}+v_{i}^{2}+w_{i}^{2}\right)$

Coupled modal mass $\left(m_{c}^{*} \mathrm{~kg} \mathrm{~m}\right)$

$$
\sum^{N} \Delta m_{i} v_{i} \sqrt{\left(x_{i}^{2}+y_{i}^{2}\right)}
$$

$$
\text { Coupled factor (a) } \quad m_{c}^{*} / m^{*}
$$

Equivalent mass $\left(I p_{e q} \mathrm{~kg} \mathrm{~m}^{2}\right) \quad a^{2} \mathrm{~m}^{*}$

Equivalent spring $\left(k_{e q} \mathrm{Nm} / \mathrm{rad}\right) \quad \omega^{2} I p_{e q}$

Residual mass $\left(\Delta I p \mathrm{~kg} \mathrm{~m}^{2}\right) \quad I p-I p_{e q}$

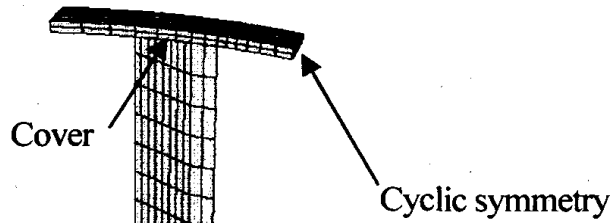

Node : 2007

Elements: 1,334

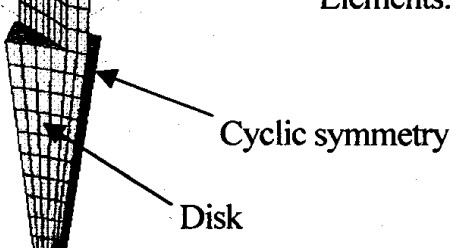

Fig. 6 Blade-disk mesh model

ANSYS $^{\circledR}$ により上記モデルでの周方向アンブレラ モ一ドの等価定数を回転数 $600 \mathrm{rpm}$ で計算した結果を 表 1 に示す.

Table 1 Modal parameters $(600 \mathrm{rpm})$

\begin{tabular}{|l|l|}
\hline Blade Frequency $(\omega)$ & $77.2 \mathrm{~Hz}$ \\
\hline Moment of Inertia $(I p)$ & $82.8 \times 10^{-3} \mathrm{~kg} \mathrm{~m}^{2}$ \\
\hline Equivalent mass $\left(I p_{e q}\right)$ & $9.80 \times 10^{-3} \mathrm{~kg} \mathrm{~m}^{2}$ \\
\hline Equivalent spring $\left(k_{e q}\right)$ & $23.1 \times 10^{2} \mathrm{~N} \mathrm{~m}$ \\
\hline Residual mass $(\Delta I p)$ & $73.0 \times 10^{-3} \mathrm{~kg} \mathrm{~m}^{2}$ \\
\hline
\end{tabular}

計算結果から，この翼モデルでは翼質量の $11.9 \%$ $\left(I p_{e q} I p\right)$ が据り連成に寄与する部分に, 残りの $88.1 \%$ $(\Delta I p / I p)$ が連成に寄与しない部分へ分けられたこと が分かる.

\section{$3 \cdot 3$ 等価樎小モデルよる翼軸連成摸り振動解析} 前節で計算したモーダル量を利用してモデルロータの 等価縮小モデルによる翼軸連成据り振動解析を行う. 解析は通常の据り振動解析であり，ANSYS ${ }^{\circledR}$ 場合は 軸に 1 次元梁要素を使い，回転慣性と回転バネに質量 要素(MASS21)とばね要素(COMBIN14)を使用する。図 7 に林図（要素数 93）を，計算結果のモード図を図 8 に示す.

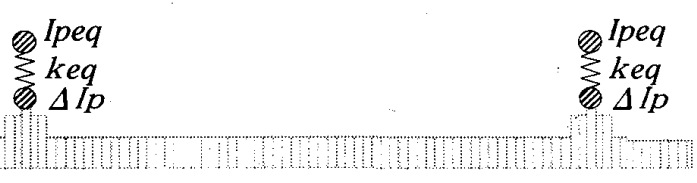

Fig. 7 Rotor-blade coupled torsional vibration model
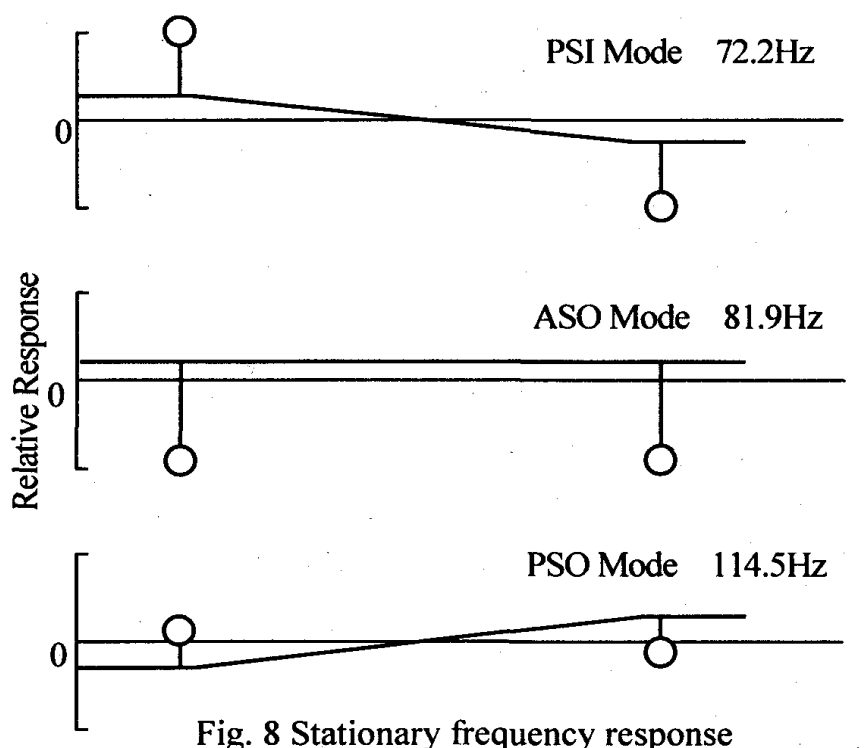

Fig. 8 Stationary frequency response

図 8 の結果から(1)奇対称同相モード（Point Symmetric In-phase mode, PSI モード)は, $72.2 \mathrm{~Hz}$ (2) 偶 対称逆相モード (Axisymmetric Out-of-phase mode, ASO

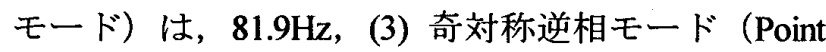
Symmetric Out-of-phase mode, PSO モード) は, $114.5 \mathrm{~Hz}$ に現れていることがわかる.これはダブルフロータイ プの実機タービンロータで現れる典型的なモードであ $ろ^{(10)}$.

図 9 は, 翼・ディスク円盤系の非連成の固有振動数 と翼・ディスク円盤系を剛とした時のシャフトの非連 成据り振動数が連成してスプリットした関係を示す. 翼を威とした時の軸単独㧖れ振動数は $104.9 \mathrm{~Hz}$ であり, 翼単独の固有振動数 $77.2 \mathrm{HZ}$ より高く, 比較的近接し ているケースである.このモデルの場合は高い方の連 
成振動数は軸単独振動数よりさらに高くなり，低い方 の連成振動数は翼単独振動数よりさらに低くなること がわかる.

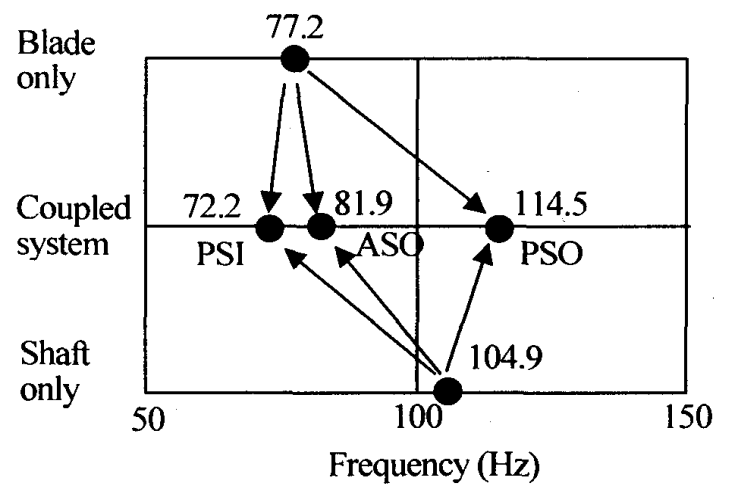

Fig. 9 Eigenvalue split at $600 \mathrm{rpm}$

\section{3-4 有限要素法モデルによる翼軸連成㧖り振動解析}

図 10 に，ロータ采全体を有限要素法で解析し，等価 縮小モデルによる解析結果と比較するための有限要素 法ANSYS によるメッシュ図を示す。

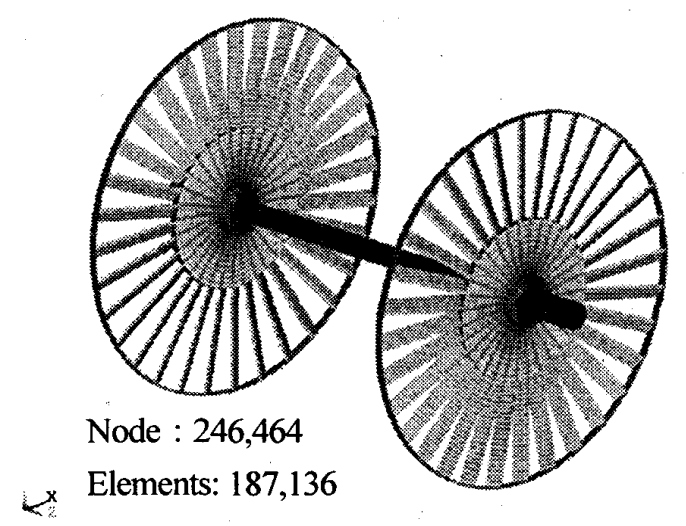

Fig. 10 Rotor mesh model

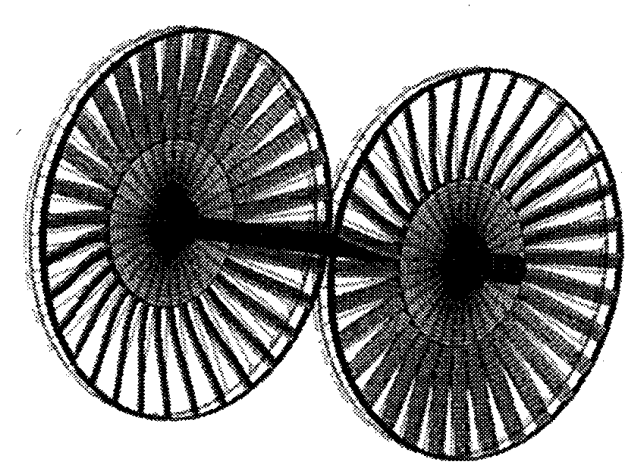

Fig. 11 Umbrella mode
このモデルで計算した場合は高次モードまで計算さ れるので, モード変形図により, アンブレラモードの 振動数を確認した. 図 11 にアンブレラモード図の 1 例を示す，表 2 に全有限要素モデルによる計算結果と 等価縮小モデルによる計算結果との比較を示す．この 結果からわかるように，両方の解析結果はよく一致し

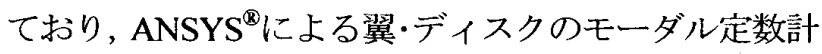
算を利用した等価縮小モデル化手法が翼軸連成㨭り振 動解析に有效な解析方法であることが確認された。

等価縮小モデルでの計算は 1 次元での計算であり， 解析設計時間も完全 FEM に比較して, 経験值として 約 $1 / 10$ から約 $1 / 20$ で斉む. 完全 FEM と同等の精度で 翼軸連成振動数をチューニングする為のシャフト形状 パラメーターサベイが短時間で繰り返し計算出来るこ とは，実用上のメリットが大きい．

Table 2 Coupled umbrella frequency at $600 \mathrm{rpm}$

\begin{tabular}{|l|c|c|}
\hline & $\begin{array}{c}\text { Equivalent reduced } \\
\text { modeling }\end{array}$ & $\begin{array}{c}\text { Full FEM } \\
\text { analysis }\end{array}$ \\
\hline PSI mode & $72.2 \mathrm{~Hz}$ & $73.8 \mathrm{~Hz}$ \\
\hline ASO mode & $81.9 \mathrm{~Hz}$ & $82.0 \mathrm{~Hz}$ \\
\hline PSO mode & $114.5 \mathrm{~Hz}$ & $115.8 \mathrm{~Hz}$ \\
\hline
\end{tabular}

\section{4. 試雅轺果}

$4 \cdot 1$ 単独翼・ディスク静止時測定結果 製作し た 2 枚のディスク（TP1 と TP2）の全周 1 リング構造 としての製作精度を確認するために，打撃試験により 単独ディスクの静止時周波数特性を測定し，モード分 析も行った. 検討の対象とした節直径数 0 次のアンブ レラモード以外の高次モードも含めて，固有振動数試 験結果と節直径数の関係を図 12 に示す。解析值と害 測值は高次モ一ドまでほぼあっており，設計意図どう りに製作されたことがわかる.

\section{4-2 翼·ディスク·軸系モデル回転試験轺果 回} 転時 $(600 \mathrm{rpm})$ の各ディスクの翼根元に取り付けたス トレングージからの出力を周波数分析した結果を図 13 に示寸. 今回の測定では, 奇対称逆相モード (PSO モード）は明確に測定出来なかった，筆者らの経験で は，実機においてもこのモードは検出することが困難 である. 表 3 に600rpm での㨭り連成振動数を等価縮小 モデルによる計算結果と比較して示す. 表 3.の結果か ら実測値は解析值とほぼ合っていることが確認された。 


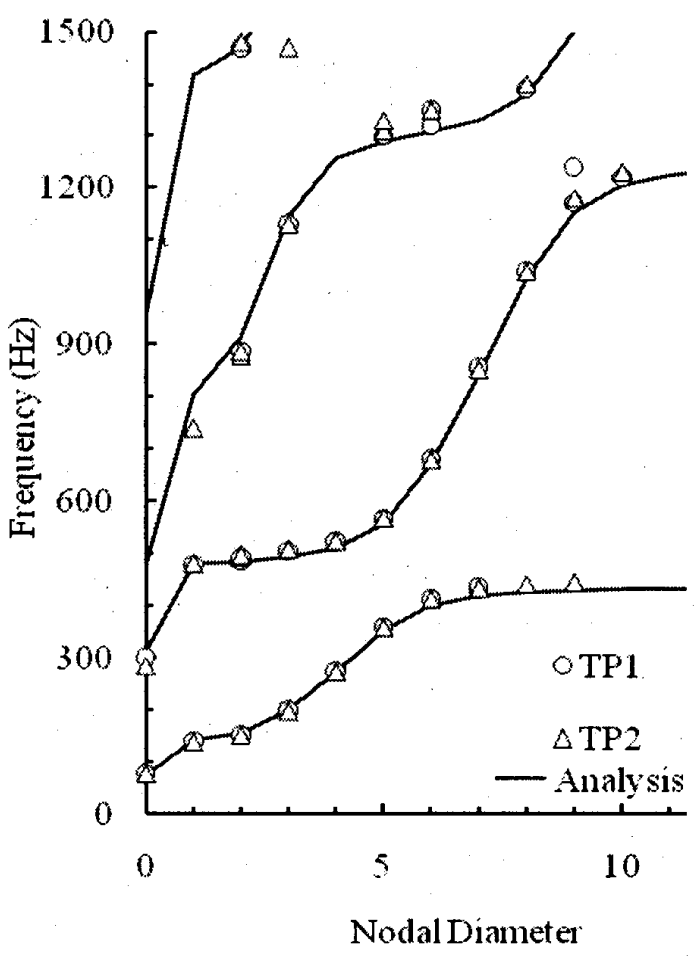

Fig. 12 Stationary nodal frequency

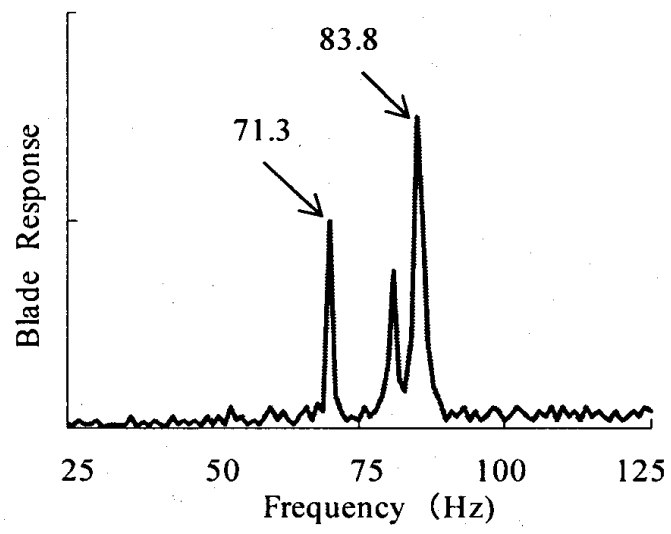

Fig. 13 Frequency response at $600 \mathrm{rpm}$

Table 3 Coupled umbrella frequency at $600 \mathrm{rpm}$

\begin{tabular}{|c|c|c|}
\hline Mode & $\begin{array}{c}\text { Calculated } \\
\text { (Equivalent } \\
\text { reduced modeling) }\end{array}$ & Measured \\
\hline PSI & $72.2 \mathrm{~Hz}$ & $71.3 \mathrm{~Hz}$ \\
\hline ASO & $81.9 \mathrm{~Hz}$ & $83.8 \mathrm{~Hz}$ \\
\hline PSO & $114.5 \mathrm{~Hz}$ & $\mathrm{~N} / \mathrm{A}$ \\
\hline
\end{tabular}

4 - 3 試験結果による等価定数の補正＼cjkstart等価縮小 モデルの大きなメリットのひとつは，物理的イメージ が明確であり，実験結果による定数の補正が可能な点 にある. 今回の実験モデルはダブルフロ一低圧蒸気夕 一ビンを想定した実験モデルであるが，このモデルの 場合の奇対称同相モード（PSI モード）と，偶対称逆相 モード (ASO モード).について補正する計算手法を以 下に説明する。

\section{ステップ 1 : 等価ばね定数補正}

ASO モ一ドが翼主体のモードであることに着目し，等 価ばね定数のみを補正して, ASO モ一ドを実測值に合 わせる．表4に補正結果を示す．

Table 4 Calibration results

\begin{tabular}{|l|c|c|}
\hline & Calculated & Step1 Calibration \\
\hline Blade frequency & $77.2 \mathrm{~Hz}$ & $78.9 \mathrm{~Hz}$ \\
\hline Equivalent spring & $23.1 \times 10^{2} \mathrm{~N} \mathrm{~m}^{2}$ & $24.1 \times 10^{2} \mathrm{~N} \mathrm{~m}$ \\
\hline Equivalent mass & $9.80 \times 10^{-3} \mathrm{~kg} \mathrm{~m}^{2}$ & $9.80 \times 10^{-3} \mathrm{~kg} \mathrm{~m}^{2}$ \\
\hline $\begin{array}{c}\text { Equivalent } \\
\text { mass ratio }\end{array}$ & $11.9 \%$ & $11.9 \%$ \\
\hline PSI mode & $72.2 \mathrm{~Hz}$ & $73.6 \mathrm{HZ}$ \\
\hline ASO mode & $81.8 \mathrm{~Hz}$ & $83.7 \mathrm{~Hz}$ \\
\hline
\end{tabular}

ステップ 2 : 等価質量補正

等価マスを補正することで，2つの振動数の差であ るスプリット量が変化することに着目し， ステップ 1 の翼単独振動数を固定して，等価質量を補正してスプ リット量を広げる。

ステップ 3 : 等価ばね定数補正

ステップ 2 で ASO モードの振動数が変化するので, 再度ステップ 1 と同じく，ステップ 2 の等価質量を固 定して，等価ばね定数を補正して ASO モードと PSI モー ドの振動数を補正する．表 5 に補正結果を示す．この 結果, ステップ 3 の補正で実測値と解析値は $1 \%$ 以下 の精度で合わせ込むことが出来たことがわかる.

Table 5 Calibration results

\begin{tabular}{|l|c|c|}
\hline & Step2 Calibration & Step3 Calibration \\
\hline Blade frequency & $78.9 \mathrm{~Hz}$ & $74.7 \mathrm{~Hz}$ \\
\hline Equivalent spring & $50.6 \times 10^{2} \mathrm{~N} \mathrm{~m}^{2}$ & $45.3 \times 10^{2} \mathrm{~N} \mathrm{~m}^{-3}$ \\
\hline Equivalent mass & $20.6 \times 10^{-3} \mathrm{~kg} \mathrm{~m}^{2}$ & $20.6 \times 10^{-3} \mathrm{~kg} \mathrm{~m}^{2}$ \\
\hline $\begin{array}{c}\text { Equivalent } \\
\text { mass ratio }\end{array}$ & $24.9 \%$ & $24.9 \%$ \\
\hline PSI mode & $74.2 \mathrm{~Hz}$ & $71.4 \mathrm{HZ}$ \\
\hline ASO mode & $88.0 \mathrm{~Hz}$ & $83.1 \mathrm{~Hz}$ \\
\hline
\end{tabular}




\section{5. 結 言}

ロータに相当する主系と翼・ディスク系を模擬 した従系からなる翼軸連成振動問題に関し，翼・ ディスク系を汎用有限要素法プログラムである ANSYS $^{\circledR}$ により固有值モ一ド解析をおこなな，擬モ一 ダル変換法による 1 自由度系の等価縮小モデルに 変換するハイブリッド方法により，ロータ系の翼 軸連成振動解析を行った。

等価縮小モデル解析と合わせて，ロータ系全体を 有限要素法で解析し，等価縮小モデルによる解析結果 と比較し，両者がほとんど同じ結果を与えることを確 認した，等価縮小モデル化手法を適用すれば，解析設 計時間も完全 FEM に比較して, 経験値として約 $1 / 10$ から約 $1 / 20$ で済むので完全 FEM と同等の精度で翼軸 連成振動数を計算でき，実用上有効である。

解析したロータ系についてモデルロータを製作し， 600rpm で回転させて翼軸連成㧖り振動数を実測した。 この結果，解析值とよく合っていることを確認した.

さらに，実験結果のアンブレラ振動数実測值を利 用して，等価定数を補正する手法を提案し，補正 された等価定数を利用することで，ロー夕系翼軸 連成据り振動数と実測振動数を $1 \%$ 以下の精度で合 わせ込むことが可能なことを示した ${ }^{(12)}$.

本モデル化は物理的理解が容易であるのみならず, 汎用の有限要素法振動解析プログラムにより, 翼振動 のアンブレラモードの等価質量と等価ばねを翼の詳細 構造を反映して定義できる。これにより，1 自由度系 等価縮小モデルへの展開が精度よく可能となり, 完全 有限要素法モデルによる解析結果と同等の翼軸連成据 り振動数評価を短時間で容易に計算可能となった。

また，実測結果によって補正された等価質量・ばね を利用することで, 例えば, 同一コンポーネントや駆 動系, 被駆動系の軸径が連結された最終軸系での翼軸 連成㧖り連成振動数を, より精度良く推定することに も資すると考えられる.

なお，記載の社名および製品名は各社の商標または 登録商標である。

\section{文献}

(1) Kosinov, Y. P. and Filippov, A. P., Vibration of rotors in turbine units with short circuit of the generator, Teploenergetica, Vol. 21, No.6 (1974), pp. 97- 101.

(2) La Rosa, J. A., Kung, D. G. C., and Rosard, D. D., Analysis of turbine blade vibration induced by electrical-mechanical interactions, Joint Conferece on Power Generation, (1980).
(3) Hammons, T. J., Stressing of large turbinegenerators at shaft couplings and LP turbine final-stage blade roots following clearance of grid system faults and faulty synchronisation, Joint Conference on Power Generation, (1986), pp. 1-12.

(4) Manabe, K., Torsional vibration measurements by generator L-L short-circuit at Ikata No.l power station (in Japanese), Sikoku Electric Power Company report, No. 40 (1982), pp. 1-6.

(5) Higuchi, M. and Tsuda, T., Telemetry test of blade shaft coupled torsional vibration at the Tsuruga No.2 Power Plant, American Power Conference, Vol. 51 (1989), pp. 1-6.

(6) Ziebarth, H. and Termuehlen, H., Evaluation method for the coupled system of shaft torsion and LP turbine blade deflection, American Power Conference, Vol. 51 (1989), pp. 1-7.

(7) Matsushita, O., Sugaya, T., Namura, K., Okabe, A., Kaneko, R., Michimura, S., and Ida, M., An equivalent reduced system for coupled vibration analysis (in Japanese), Transactions of the Japan Society of Mechanical Engineers, Series C, Vol. 54, No.499 (1988), pp. 587-595.

(8) Matsushita, O., Namura, K., Yoshida, T., Kaneko, R., and Okabe, A., Torsional vibration analysis of turbine-generator-blade coupled system, American Power Conference, Vol. 51 (1989), pp. 81-86.

(9) Okabe, A., Kaneko, R., Matsushita, O., Namura, K., and Yoshida, T., Coupled vibration analysis: torsional vibration of turbine-generator coupled system, 12th ASME Conferene on Mechanical vibration and noise, Vol. 18 (1989), pp. 135- 140.

(10) Okabe, A., Kudo, T., Yoda, H., Sakurai, S., Matsushita, O., and Shiohata, K., Rotor-Blade Coupled Vibration Analysis by Measuring Modal Parameters of Actual Rotor (in Japanese), Transactions of the Japan Society of Mechanical Engineers, Series $C$, Vol. 75, No.751 (2009), pp. 566-573.

(11) Namura, K., The vibration characteristics of steam turbine blades (in Japanese), Transactions of the Japan Society of Mechanical Engineers, Series $C$, Vol. 51, No.466 (1985), pp. 1245-1254.

(12) ISO 22266-1:2009(E), Mechanicalvibration-Torsional vibration of rotating machinery-, Part 1: Land-based steam and gas turbine generator sets in excess of $50 \mathrm{MW},(2009)$. 